\title{
Засоби фізичної терапії при артеріальній гіпертензії у жінок похилого віку
}

\author{
УДК: 615.8: 616.8-009.12 \\ і. В. Шаповалова, Є. А. Захаріна
}

Запорізький державний медичний університет, Запоріжжя, Україна Класичний приватний університет, Запоріжжя, Україна

\begin{abstract}
Анотація. Мета. Обґрунтувати ефективність застосування гідрокінезитерапії під час фізичної терапії жінок похилого віку, хворих на артеріальну гіпертензію. Методи. Педагогічні, функціональні, теоретичний аналіз та методи математичної обробки даних. Визначено діагностичний інструментарій дослідження. Залучено до експерименту 46 хворих на артеріальну гіпертензію жінок віком від 60 до 70 років, яких розподілено на дві групи: контрольну (КГ) - 24 особи, та експериментальну (ЕГ) - 22 особи. Результати. Доведено ефективність гідрокінезитерапії у фізичній реабілітації жінок похилого віку, хворих на артеріальну гіпертензію. Встановлено позитивні зміни з боку функціонального стану серцево-судинної системи. Висновок. Програма гідрокінезитерапіі для жінок похилого віку, хворих на артеріальну гіпертензію, сприяє зниженню артеріального тиску, зменшенню частоти серцевих скорочень, зменшенню головного болю, припиненню запаморочення, нормалізації сну, покращенню емоційного стану.
\end{abstract}

Ключові слова: артеріальна гіпертензія, гідрокінезотерапія, реабілітація.

Physical therapy means for arterial hypertension in elderly women V. Shapovalova, I. A. Zakharina

Zaporizhzhia State Medical University, Zaporizhzhia Classic Private University, Zaporizhzhia

Abstract. The article substantiates the effectiveness of hydrokinesitherapy usage for the rehabilitation of elderly women with arterial hypertension. Methods: pedagogical, functional, theoretical analysis, and methods of mathematical processing of data. The diagnostic tool of research is determined. 46 women aged 60 to 70 years old with hypertension were included in the experiment and divided into two groups: control $(C G)-24$, and experimental (EG) 22 women. Results. The effectiveness of hydrokinesitherapy in physical rehabilitation of elderly women suffering from arterial hypertension is proved. Positive changes in the functional state of the cardiovascular system are established. It is concluded that the program of hydrokinesitherapy for the elderly patients with arterial hypertension contributes to decrease of blood pressure and heart rate, reduces headache, eliminates dizziness, normalizes sleep, improves emotional state.

Keywords: arterial hypertension, hydrokinesitherapy, rehabilitation.

Постановка проблеми. Наразі захворювання серцево-судинної системи посідають одне 3 перших місць за частотою й потребують своєчасної діагностики та профрілактики. Поширеність серцево-судинних захворювань серед українців за останні 25 років зросла в 3 рази, через що в Україні чи не найвищий серед країн Європи рівень смертності від зазначеного діагнозу [12]. За даними ВООЗ, артеріальна гіпертензія - серед 10 провідних причин смерті у світі, частка якої становить 48,6 \% [18]. Згідно зі статистичними даними, майже у $15 \%$ населення (з-поміж яких майже половина жінок віком від 50 років) - діагноз: артеріальна гіпертензія [5]. Незважаючи на розвиток сучасних технологій в медичній галузі, значного прогресу щодо збільшення тривалості життя не спостерігається.

Аналіз останніх досліджень і публікацій. Зарубіжні дослідники [17] виявили, що серцеві недуги та аритмія $€$ поширеним явищем у процесі старіння - це пов'язано зі збільшенням серцевих електрофрізіологічних і вегетативних розладів. Вітчизняні вчені О. Івановська [4], В. Манжуловський [10], В. Педаєва [12], 
А. Саїнчук [14] основною причиною високої захворюваності та смертності людей від серцевосудинних захворювань називають гіпокінезію, що $€$ пусковим механізмом розвитку захворювань. Науковці пропонують застосовувати засоби та методи фрізичної терапії для їхньої профрілактики.

Як зазначає Р. Григорян [3], глибинні механізми етіології та патофрізіології артеріальної гіпертензії до кінця не вивчені, що робить з'ясування ії причин актуальним для науки й практичної медицини.

Незважаючи на сучасні методи фрізичної терапії, медикаментозна терапія до цього часу залишається найпоширенішим методом лікування гіпертонічної хвороби. Кількість нових препаратів для боротьби з цим захворюванням тільки збільшується, однак досягти цільового рівня артеріального тиску вдається не завжди.

Такі дослідники, як А. Киселев [6] та К. Ланфран [8], вважають, що використання немедикаментозних методів $€$ досить актуальним питанням профрілактики та боротьби з артеріальною гіпертензією, а одне з першочергових завдань сучасної охорони здоров'я - проведення ефективних методів первинної та вторинної профрілактики серцево-судинних захворювань $[6,8]$.

Так, С. Абрамович [1] констатує, що в останні десятиліття в кардіореабілітації осіб старшого і похилого віку стали активно застосовуватися природні та преформовані фрізичні фактори.

У сучасній вітчизняній та зарубіжній медичній літературі велику кількість робіт присвячено різним аспектам лікування серцево-судинних захворювань, у тому числі й за допомогою методів фрізичної реабілітації [9].

Тому в сучасному суспільстві розробка програм і заходів щодо підвищення рівня рухової активності для різних груп населення з різним станом здоров'я $\epsilon$ надзвичайно важливим завданням.

Зв'язок роботи 3 науковими програмами. Дослідження проведенов межах напряму науково-дослідної роботи кафедри фрізичної реабілітації та здоров'я людини Інституту здоров'я, спорту і туризму імені Т. Самоленко Класичного приватного університету «Індивідуалізація заходів фрізичної реабілітації щодо осіб з особливими потребами і спортсменів» (номер державної реєстрації 0113U000580).

Мета дослідження - обгрунтувати ефективність застосування гідрокінезитерапії під час фрізичної терапії жінок похилого віку, хворих на артеріальну гіпертензію; розробити програму гідрокінезитерапії для жінок похилого віку, хворих на артеріальну гіпертензію; експериментально перевірити ефрективність запропонованої програми.
Методи та матеріали дослідження. В основу роботи покладено теоретичний аналіз науковометодичної літератури, педагогічні та фуннкціональні методи, методи математичної статистики. Дослідження проведено на базі басейну «Спартак» Класичного приватного університету в період 3 жовтня 2018 р. по травень 2019 р. До експерименту було залучено 46 хворих на артеріальну гіпертензію жінок віком від 60 до 70 років, яких було розподілено на дві групи: контрольну (КГ) - 24 особи та експериментальну (ЕГ) - 22 особи.

Результати дослідження. Артеріальна гіпер-

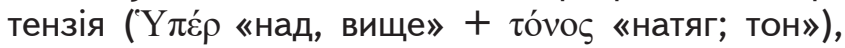
характеризується підвищенням артеріального тиску: систолічного - понад 140 мм рт. ст. та діастолічного - від 90 мм рт. ст. Це пов'язано зі збільшенням тонусу судин, що створює підвищену опірність кровотоку. Основною причиною артеріальної гіпертензії $\epsilon$ порушення функцій вищих відділів ЦНС, розлад нейрогуморальних механізмів.

До чинників, що спричиняють підвищення артеріального тиску, відносять психоемоційні перенапруження, часті стреси, надмірну розумову працю, атеросклероз, спадковість, ожиріння, діабет, клімакс, паління тощо. Хвороба має хронічний перебіг з періодичними загостреннями, гіпертонічними кризами та періодами ремісії; проявляється головним болем, запамороченням, шумом у вухах, підвищеною дратівливістю, зниженням працездатності [14, с. 236].

Як зазначає О. Івановська [3], застосування гідрокінезитерапії грунтується на властивостях води й особливостях ї̈ впливу на організм. Передусім використовується механічна дія водного середовища, іiї виштовхувальна підйомна сила та гідростатичний тиск. Це значно полегшує виконання вправ і дає змогу при мінімальному м'язовому зусиллі виконувати активні рухи, збільшити амплітуду руху, відновити локомоторну функцію. Гідростатичний опір сприяє компресії перифреричних судин, покращує їхню еластичність та сприяє поліпшенню відтоку крові по венозній системі. Велике значення для зміни кровообігу має розширення кровоносних судин шкіри, які можуть вмістити до 1 л крові, - тому шкіра має велике значення і як депо крові, фрункції якої систематично поліпшуються під впливом низьких температур. У цих умовах серцевому м'язу працювати значно легше [4, с. 53].

Найкращою гімнастикою при артеріальній гіпертензії вважається вплив низьких температур води та повітря, гідромасаж шкіри, що викликає скорочення, а потім розслаблення найменших судин організму людини. Безпосередньо на заняттях гідрокінезитерапією спостерігається 
ТАБЛИЦЯ 1 - Показники клінічних проявів артеріальної гіпертензії у жінок похилого віку (за: Саїнчук [13])

\begin{tabular}{|l|c|c|c|c|}
\hline \multirow{2}{*}{ Скарги } & \multirow{2}{*}{ Групи } & \multicolumn{2}{|c|}{ Дослідження } & \multirow{2}{*}{ Різниця, \% } \\
\cline { 3 - 4 } & & початок, \% & кінець, \% & \\
\hline \multirow{2}{*}{ Головний біль } & $\mathrm{KГ}$ & 100 & 45,4 & 54,6 \\
\cline { 2 - 4 } & $\mathrm{E} Г$ & 100 & 5,7 & 94,3 \\
\hline \multirow{2}{*}{ Запаморочення } & $\mathrm{K} Г$ & 43,2 & 28,4 & 14,8 \\
\cline { 2 - 4 } & $\mathrm{E} Г$ & 44,3 & 5,4 & 38,9 \\
\hline \multirow{2}{*}{ Порушення сну } & $\mathrm{K} Г$ & 31,3 & 12,6 & 18,7 \\
\cline { 2 - 4 } & $\mathrm{E} Г$ & 30,5 & 0 & 30,5 \\
\hline \multirow{2}{*}{ Дратівливість } & $\mathrm{KГ}$ & 25,2 & 14,5 & 10,7 \\
\cline { 2 - 4 } & $\mathrm{EГ}$ & 24 & 14,5 & 9,5 \\
\hline
\end{tabular}

підвищення циркуляції крові та лімфи, покращення венозної гемодинаміки, зменшуються застійні явища в організмі. Активуються резервні можливості, полегшується робота серця за рахунок ритмічних чергувань напруження та розслаблення м'язів, покращується активність рухів. Перед проведенням дослідження було визначено діагностичний інструментарій, здійснено первинне обстеження жінок у КГ та ЕГ з метою оцінювання їхнього початкового стану, виміряно частоту серцевих скорочень (ЧСС) та артеріальний тиск (AT), а також з'ясовано клінічні прояви артеріальної гіпертензії: головний біль, запаморочення, порушення сну, дратівливість - за методикою А. Саїнчук [14], адаптивний потенціал (АП), за методикою Р. М. Баєвського [2] коефіцієнт економізації кровообігу (КЕК) (табл. 1).

Досліджуваним жінкам похилого віку було запропоновано програму гідрокінезитерапії, мета якої - зниження артеріального тиску. Програма заснована на принципах свідомості і активності, забезпечення контролю адекватності навантажень, систематичності та індивідуалізації. Принцип свідомості і актиВності був спрямований на свідоме відношення та стійку мотивацію на досягнення поставленої мети. Принцип забезпечення контролю адекВатності наВантажень потрібен для визначення індивідуальної реакції організму на фрізичне навантаження засобами поточного контролю. Принцип систематичності визначався з необхідності безперервних занять, оскільки тільки при систематичному виконанні спеціальних фрізичних вправ можна отримати стійкий результат. Принцип індивідуалізації визначає індивідуальні функціональні можливості жінки, її руховий досвід, професію та психологічні особливості.

Програма гідрокінезитерапії складалась 3 трьох етапів: діагностичного, реабілітаційного та заключного. На діагностичному еmani було проведено діагностику фрункціонального стану жінок засобами пульсометрії, тонометрії, визначенням адаптаційного потенціалу Баєвського, коефіцієнта економізації кровообігу. Реабілітаційний етап складався 3 трьох блоків: підготовчого, основного та заключного. Підготовчий блок тривав 10 хв та складався з вправ на освоєння з водою, дихальних вправ, ковзання та плавання з плавальними дошками. Основний блок тривав 35 хв та складався 3 ходьби по дну на місці, ходьби з подоланням опору води, ходьби з поворотами та зміною напрямку, ходьби з різними положеннями і рухами руками, ходьби з різних вихідних положень. Застосовувались вправи з опором води для верхніх та нижніх кінцівок. Виконувались вправи $з$ нудлами для верхніх та нижніх кінцівок, вправи для тулуба. Заключний блок тривав 15 хв та складався із дихальних вправ (10-15 видихів у воду), техніки плавання обраним способом у вільному темпі, вправ на розслаблення. Тривалість заняття - 60 хв (у тому числі основної частини - 35 хв), періодичність - тричі на тиждень. Заключний етап складався 3 проведення повторного діагностичного обстеження функціональних можливостей жінок та визначення результату програми гідрокінезитерапії.

У процесі дослідження було визначено середні показники фрункціональної діагностики жінок похилого віку (табл. 2).

Результати в таблиці 2 свідчать про те, що середній показник ЧСС на початку дослідження в КГ - 73,24 уд. хв $^{-1}$, в ЕГ $-73,13$ уд. хв $^{-1}$, в кінці дослідження в КГ - 73,1 уд. $\mathrm{xв}^{-1}$, в ЕГ 68,2 уд. хв$^{-1}$, різниця становила в КГ 0,14 уд. $\cdot$ хв$^{-1}$, в ЕГ $-4,93$ уд. $\cdot$ хв$^{-1}$; середній показник АТ на початку дослідження в КГ 147,1/96,3 мм рт. ст.; в ЕГ - 146,2/96,1 мм рт. ст.; в кінці дослідження в КГ - 145,5/95,1 мм рт. ст.; в ЕГ - 130,3/80,13 мм рт. ст.; різниця становила в КГ - 1,6/1,2 мм рт. ст.; в ЕГ 15,9/15,97 мм рт. ст.

Згідно з результатами таблиці 3, показник адаптаційного потенціалу на початку дослідження в КГ 3,53 $\pm 0,141$, в ЕГ $-3,63 \pm 0,065$ ( $>>0,05)$, в кінці дослідження в КГ $-3,48 \pm 0,012$, в ЕГ $3,20 \pm 0,008,(p<0,05)$, що свідчить про покращення функціональних можливостей системи кровообігу.

Показник коефіцієнта економізації кровообігу на початку дослідження в КГ 4347,81 \pm 65,53, в ЕГ $-4218,13 \pm 24,89$ ( $>>0,05)$, в кінці дослідження в КГ $-4069,76 \pm \pm 189,15$, в ЕГ $2788,17 \pm 10,77$ ( $><0,05)$, що свідчить про наближення показника коефріцієнта економізації кровообігу до норми.

Висновки та перспективи подальших досліджень. У процесі дослідження обґрунтовано й експериментально перевірено ефективність 
ТАБЛИЦЯ 2 - Середні показники функціональної діагностики жінок похилого віку

\begin{tabular}{|c|c|c|c|c|c|}
\hline \multirow{2}{*}{ Показник } & \multirow{2}{*}{ Група } & \multicolumn{4}{|c|}{ Дослідження } \\
\hline & & \multicolumn{2}{|c|}{ початок } & \multicolumn{2}{|c|}{ кінець } \\
\hline \multirow[t]{2}{*}{ ЧСС, уд. $\cdot$ хв $^{-1}$} & КГ & \multicolumn{2}{|c|}{73,24} & \multicolumn{2}{|c|}{73,1} \\
\hline & $\mathrm{E} \Gamma$ & \multicolumn{2}{|c|}{73,13} & \multicolumn{2}{|c|}{68,2} \\
\hline \multirow{2}{*}{$\begin{array}{l}\text { АТ (систолічний, } \\
\text { діастолічний), } \\
\text { мм рт. ст. }\end{array}$} & КГ & 147,1 & 96,3 & 145,5 & 95,1 \\
\hline & ЕГ & 146,2 & 96,1 & 130,3 & 0,13 \\
\hline
\end{tabular}

ТАБЛИЦЯ 3 - Показники функціональної адаптації жінок похилого віку до фізичного навантаження

\begin{tabular}{|l|c|c|c|}
\hline \multicolumn{1}{|c|}{ Показник } & Групи & $\begin{array}{c}\text { На початку } \\
\text { дослідження } \mathbf{M} \pm \mathbf{m}\end{array}$ & $\begin{array}{c}\text { В кінці } \\
\text { дослідження } \mathbf{M} \pm \mathbf{m}\end{array}$ \\
\hline $\begin{array}{l}\text { Адаптаційний по- } \\
\text { тенціал (за методикою }\end{array}$ & КГ & $3,53 \pm 0,141^{*}$ & $3,48 \pm 0,012^{* *}$ \\
\cline { 2 - 4 } $\begin{array}{l}\text { Р. М. Баєвського) } \\
\text { Коефіцієнт економіза- } \\
\text { ції кровообігу }\end{array}$ & КГ & $3,63 \pm 0,065^{*}$ & $3,20 \pm 0,008^{* *}$ \\
\cline { 2 - 4 } & ЕГ & $4218,13 \pm 24,89^{*}$ & $2788,17 \pm 10,77^{* *}$ \\
\hline
\end{tabular}

${ }^{*} p<0,05$. ${ }^{* *} p<0,05$. застосування гідрокінезитерапії під час фрізичної терапії жінок похилого віку, хворих на артеріальну гіпертензію, про що свідчить порівняльний аналіз результатів функціональної діагностики на початку та в кінці дослідження з позитивною динамікою.

Доведено, що програма гідрокінезитерапії для жінок похилого віку $є$ ефективним засобом фрізичної реабілітації артеріальної гіпертензії та сприяє зниженню артеріального тиску, зменшенню часто-

\section{Література}

1. Абрамович СГ. Применение лечебных физических фракторов у больных гипертонической болезнью пожилого возраста [The use of therapeutic physical factors in elderly patients with hypertension]. Сибирский медицинский журнал. 2008; 4:5-8.

2. Баевский РМ. Прогнозирование состояний на грани нормы и патологии [Prediction of conditions on the verge of norm and pathology]. Москва: Медицина; 1999. 298 с.

3. Григорян РД. Энергетический аспект этиологии артериальной гипертензии [The energy aspect of the etiology of arterial hypertension]. Доповіді Національної академії України. 2014; 9:116-122.

4. Івановська ОЕ. Програма фрізичної реабілітації жінок другого зрілого віку з екзогенно-конституціональним ожирінням з використанням методів гідрокінезитерапії [Physical Rehabilitation Program for Second-Mature Women with Exogenous-Constitutional Obesity Using Hydro kinesitherapy] [дисертація]. Київ; 2018. 219 с.

5. Калмикова ЮС, Калмиков СА, Садат КН. Застосування засобів фрізичної терапії у відновному лікуванні гіпертонічної хвороби [The use of physical therapy means for treating hypertension]. Фізична реабілітація та рекреаційно-оздоровчі технології. 2017; 1: 16-26.

6. Киселев АР. Профилактика и лечение артериальной гипертонии в амбулаторных исследованиях с использованием мобильной телефонной связи и интернет-технологий [Prevention and treatment of arterial hypertension in outpatient studies using mobile telephony and Internet technologies]. Терапевтический архив. 2011; 4: 46-52.

7. Козубенко ЮЛ. Особливості проведення занять з лікувальної фрізичної культури при гіпертонічній хворобі [The pecularities of conducting health related physical culture sessions during hypertension ]. Молодий вчений. 2016; 5: 340-344.

8. Ланфан К. Артериальное давление: каковы наши успехи в его снижении [Blood pressure: what are our successes in reducing it]. Терапевтический архив. 2009; 5: 47-50.

9. Ломаковский А. Физическая реабилитация пациентов с артериальной гипертонией [Physical rehabilitation of patients with arterial hypertension]. Молодіжний науковий вісник Східно- ти серцевих скорочень, полегшенню головного болю, припиненню запаморочення, нормалізації сну, покращанню емоційного стану.

Перспективи подальших досліджень вбачаємо у проведенні наукових розвідок, пов'язаних із поглибленим вивченням засобів фрізичної терапії для жінок з артеріальною гіпертензією, та в розробці методичного інструментарію щодо реабілітаційних заходів.

європейського національного університету імені Лесі Українки. Фізичне виховання і спорт. 2014; 16: 134-139.

10. Манжуловский ВН. Прогностическая роль факторов риска при реабилитации больных сердечно-сосудистыми заболеваниями [The prognostic role of risk factors in the rehabilitation of patients with cardiovascular diseases]. Пedaгогіка, психологія та медико-біологічні проблеми фрізичного виховання і спорту. 2011; 6: 85-7.

11. Медицинская реабилитация [Medical rehabilitation]. Боголюбова ВМ, редактор. Москва: Бином; 2010. 416 с.

12. Педаєва ВО. Програма фрізичної реабілітації жінок похилого віку, хворих на гіпертонічну хворобу II ступеня [The program of physical rehabilitation of a elderly women with hypertension of the second degree]. Науковий часопис НПУ імені М. П. Драгоманова. 2015; 4: 63-5.

13. Прокопец ТП. Поэтапная оздоровительно-образовательная программа профилактики и реабилитации пациентов с сердечно-сосудистыми заболеваниями [Stage-by-stage health related and educational program for the prevention and rehabilitation of patients with cardiovascular diseases]. Вестник ТГПУ; 2008; 3: 67-71.

14. Саїнчук АМ. Фізична реабілітація хворих шийногрудним остеохондрозом і гіпертонічною хворобою [Physical rehabilitation of patients with cervical thoracic osteochondrosis and hypertension] [дисертація]. Київ; 2016. 242 с.

15. Стяжкина ЕМ. Лечебная гимнастика в бассейне с включением интервальных физических тренировок у пациентов с сердечно-сосудистыми заболеваниями [Therapeutic gymnastics in the pool with the inclusion of interval physical training for patients with cardiovascular diseases]. Лечебная физкультура и спортивная медицина. 2012; 10:45-50.

16. Blair SN. Healthy Hearts - and the Universal Benefists of Being Physically Active: Physical Activity and Health. Annals of Epidemiology; 2009; 19: 253-256.

17. Soare-Miranda L. Physical Activity and Heart Rate Variability in Older Adults. The Cardiovascular Health Study; 2016. 210 p.

18. The 10 Leading Causes of Death in the World by Percentage. World health organization; 2014. http//who.int/mediacentre/factsheets/fs310/. 